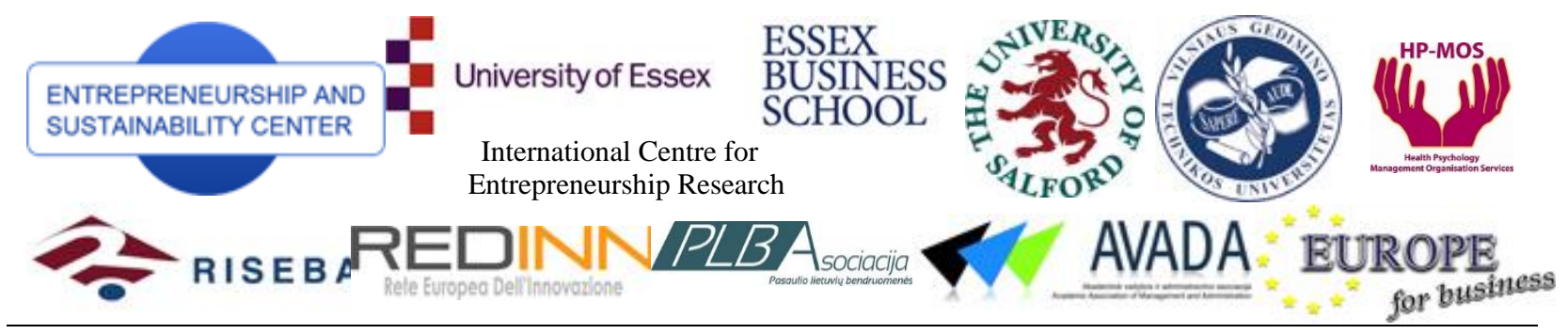

ENTREPRENEURSHIP AND SUSTAINABILITY ISSUES

ISSN 2345-0282 (online) http://jssidoi.org/jesi/

\title{
SUSTAINABLE DEVELOPMENT IN HIGHER EDUCATION THROUGH SERVICE QUALITY AND PRICE FAIRNESS: EMPIRICAL EVIDENCE FROM PRIVATE UNIVERSITIES IN DAMASCUS, SYRIA
}

\author{
Serene Dalati ${ }^{1,}$ Salah Eddin Al Hamwi ${ }^{2}$ \\ 1,2 Arab International University, Ghabagheb, Syria \\ E-mails: ${ }^{1}$ s-dalati@aiu.edu.sy; ${ }^{2}$ salahalhamwi@gmail.com
}

Received 10 March 2016; accepted 20 June 2016

\begin{abstract}
The purpose of this research is to develop a model which examines the relationship between adapted dimensions of service quality scale and customer satisfaction and perceived price fairness, building on previous measurement instrument developed by (A. Parasuraman, Zeithaml, \& Berry, 1988b). The research paper investigates the instrument at higher education in Syria. The planned methodology for the research employs a quantitative approach where the service quality instrument developed by (A. Parasuraman, Zeithaml, \& Berry, 1988a) is employed in this research. The sample of the study follows a non-probability sampling approach. The unit of analysis in this research is undergraduate students of private universities in Syria. Online selfadministered questionnaires were distributed to undergraduate students in 3 private universities in Syria. The adjusted instrument scale employed a 5 points Likert scale where 1 indicates strongly disagree and 5 strongly agree. The level of analysis investigates reliability and validity tests. Exploratory factor analysis (EFA) is employed to measure relationships between measured variables. The exploratory factor analysis produced three dimensions. Cronbach alpha test is employed to measure the internal consistency of the scale. The adapted service quality scale comprises of three dimensions namely institution task orientation, institution relationship orientation and institution tangibles orientation. The instrument consists of 12 items. The research recommends the measurement scale to be applied for service quality in Higher Education environment.
\end{abstract}

Keywords: Service Quality, SERVQUAL, SERVPERF, Higher Education, Student Satisfaction, Price Fairness

Reference to this paper should be made as follows: Dalati, S.; Al Hamwi, S. E. 2016. Sustainable development in higher education through service quality and price fairness: empirical evidence from private universities in Damascus, Syria, Entrepreneurship and Sustainability Issues 4(1): 25-38. DOI: http://dx.doi.org/10.9770/jesi.2016.4.1(3)

JEL Classifications: A2, A29 


\section{Introduction}

Providing service quality has become a priority for service organizations and competitive advantage (Vojtovič \& Navickas, 2016; Aleksejeva, 2016; Dobele et al. 2016; Prause 2015; Čirjevskis 2015; Dzemyda et al. 2015). Understanding the factors that affect students' perception of a service is a significant dimension to understand their attitudes and perception about the service. In higher education, there are problems of structure, personalities, students, academic staff, physical environment, university staff and management (Rosha, Lace, 2015), (Prause, 2015); ( Dubauskas, Balius, 2015); (Goyal, Sergi, 2015).

In order to maintain contemporary required level, universities have to interact with industry and other stakeholders (Ciemleja, Lace, 2015; Tvaronavičienè, Černevičiūtè, 2015, Čirjevskis, 2015, Djordjevic \& Cotton, 2011). All this creates a complex situation in which higher education is assessed on bases of how well students are satisfied, what is valued by students, how students perceive the quality of education and how these can be improved. In today's competitive academic environment, students have many options available. There are factors that enable educational institutions to attract and retain students including service quality. Private universities are profit-based organizations selling educational services to students as their primary customers. A prior study has identified that regarding students as customers is not a very new idea. Previously, students were considered as consumers of service; with the introduction of private institutions, where students consciously pick, choose and buy the service; therefore, they have the right to be regarded as customers being "partners" in the learning process (Douglas, Douglas, \& Barnes, 2006).

In today's competitive academic environment where students have many options available to them, factors that enable educational institutions to attract and retain students should be very significant. Higher education institutions need to begin searching for effective and creative ways to attract, retain and foster stronger relationships with students. In this study, students are treated as customers, which are the lifeline in any business. Increasing student satisfaction ultimately leads to an increase in loyalty for the Higher Education institution. An increased level of globalization caused consumer knowledge and awareness in developing to increase. This gave consumers the ability to see and exhibit different quality standards established by companies around the world, which helped in setting up an expectation and perception platform for customers.

\section{Service Quality}

Better understanding of service quality requires the examination of three characteristics namely intangibility, heterogeneity and inseparability (Parasuraman, Zeithaml, \& Berry, 1985). Services are intangible because performance of the service varies and is not standardized. Secondly services are heterogeneous as they vary from time to time and from one producer to another. Consistency of behaviour is not possible. What the service provides, or intends to provide could be different from what the customer receives. Thirdly services have the characteristic of inseparability. Production and consumption occurs at the same time (A. Parasuraman et al., 1985). Figure 1 illustrates characteristics of services as illustrated by Parasuraman et al 1985. 


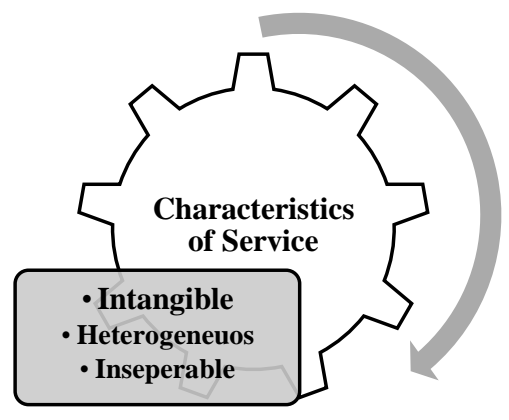

Figure 1. Characteristics of Service Source: Parasuraman et al 1985

The SERVQUAL instrument measures service quality by finding the difference-score between perception and expectation of customers. In early stage, Parasuraman, et al. (1985), introduced ten service quality determinants, then the ten determinants were redefined and some emerged to formulate the new five service quality dimensions including reliability, responsiveness, assurance, empathy, and tangibles (Parasuraman et al., 1988a).

\section{Customer Satisfaction}

High levels of satisfaction among targeted customers is good indicator of the service quality levels that they are receiving. Furthermore, raising customer expectations could increase satisfaction through perceived performance, but at the same time lower satisfaction through disconfirmation. Different satisfaction levels reflect different issues and require different actions (Oliver 1980, Abdullah et al. 2012). Consumers reach their satisfaction decisions by comparing the service performance with prior expectations about how the service would or should perform (Bitner, 1990). Bitner (1990) concluded that service quality affects customer satisfaction, which in turn affects customers' recollected perceptions of the service quality. When a customer purchase a service, their satisfaction and loyalty are affected directly and indirectly by the service quality. The study also proposed that satisfaction is largely influenced by the value and quality of the services provided to customers.

\subsection{Students as Customers}

The notion of seeing students as customers is a highly controversial and debatable. It involves several perspectives" each of which has its own reason to argue for and against the "students as customers" notion. The basic notion has a strong "common sense" appeal in terms of highlighting the need to ensure consistent quality standards. Academic staffs are the first to oppose the "students as customers" notion (Nicholls, Harris, Morgan, Clarke, \& Sims, 1995). The cost of treating students as customers carries mixed blessings, they deserve more from educators than instant gratification. Individuals that view themselves as educators rather than front line staff of a service delivery process, find it immoral to treat their students as customers because it defies their purpose and integrity. From a business perspective, it is self-evident that people who pay for a service are customers and should be treated as such. It is cheaper to retain an existing customer than to attract new customers. Thus providing customer satisfaction should assist not only in the retention of students throughout their studies, but possibly enable the relationship to continue through alumni activity post-graduation. Another similar characteristic that students have with customers is their ability to effect 
the institute's reputation through negative word of mouth which will impact future student recruitment and retention efforts (Hidalgo \& Fuentes, 2013, Merrill, 2011).

\section{Perceived Price Fairness}

Price fairness refers to consumers' assessments of whether a seller's price is reasonable, acceptable and justifiable. Charging fair price is a very important issue that leads toward satisfaction, it helps to develop customer satisfaction and loyalty. Kotler and Armstrong (2013) reported that price is the amount of money exchanged for a product or service, or the sum of the values that customers exchange for the benefits of acquiring the product or service. Zeithaml et al. (1996) stated that the customer's perceived price can be considered as what is given up or sacrificed to get a product or service. The price of a service can significantly influence perceptions of quality and satisfaction (Zeithaml 2012).

Customer satisfaction is directly influenced by price perceptions while indirectly through the perception of price fairness. The price fairness itself and the way it is fixed and offered have a great impact on satisfaction. The perception of a fair price differs amongst individuals; however, the perception of how quality is associated with price, is relatively common. Although marketing efforts try to convince consumers otherwise, low standards or quality of a service are usually associated with low price and vice versa high quality or high standards are associated with high price. Most private universities charge a relatively high price for their services, thus the student automatically assumes that he or she will receive a high quality standards service. Information including price and local ranking for most Syrian private universities can be found online, thus student satisfaction can be influenced not only by the student comparing the price of his or her choice of university to other institutes but by comparing the extra services being offered elsewhere at different price offering. In this study, the student's perceived price is what is given or sacrificed to attain educational services.

\section{Research Employed Methodology}

The research study employs a quantitative approach by the application of a multi-dimensional scale comprised of 22 items measuring service quality dimensions. Research methodology examines questionnaire design of service quality dimensions adapted from Parasuraman et al (1988).

\subsection{Questionnaire Design}

The research measurement scale is mainly based on Parasuraman, et al., 1988. However a set of factors are taken into consideration before making changes on the service quality scale. These factors include research objectives, response type, number of dimensions, number of scale points, and a balanced scale. The instrument applied a 5 point Likert scale where 1 is indicated strongly Disagree and 5 is strongly agree. Assessment of customer perception of the service quality dimensions used 22-items. Student's satisfaction applied a single item scale to measure student satisfaction with the service. Price fairness also applied a single item scale to measure price fairness of the service.

\subsection{Sampling Design}

The research employs a non-probability sampling strategy. The target study population comprises undergraduate students of three private universities in Syria providing higher education bachelor programs in different fields of studies. The unit of analysis comprises of undergraduate students belonging to the target universities. The size of the sample comprises of 107 undergraduate students studying at various major undergraduate programs at the following universities. Table 1 illustrates the sample of the study and the distribution among three target higher education institutions. 
Table 1. Research Sampling Design $(\mathrm{n}=107)$ 2016 Volume 4 Number 1 (September

\begin{tabular}{|l|l|l|}
\hline University & $\%$ & Sample size. \\
\hline AIU & 48.6 & 52 \\
\hline IUST & 29.9 & 32 \\
\hline YPU & 21.5 & 23 \\
\hline Total & 100 & 107 \\
\hline
\end{tabular}

Source: author

\section{Exploratory Factor Analysis}

To examine the validity of the applied SERVEPERF service quality scale in the target sample selected from private universities in Syria an exploratory factor analysis is performed. An exploratory factor analysis is conducted to examine the validity of the SERVPERF adapted scale. An exploratory factor analysis is employed when there is uncertainty about the factors which exist in a set of variables (Zikmund, Babin, Carr, \& Griffin, 2009, Hair, Black, Babin, \& Anderson, 2010). The results of the exploratory analysis produced three factors with an Eigen value above 1 and factor loading which is above 0.30. Kaiser Meyer Olkin measure of sampling adequacy is 0.769 indicating that the factor analysis produced reliable and distinct factors. The original scale of SERVQUAL, and SERVPERF produces five dimensions measuring service quality. The factor analysis identified three significant factors measuring three dimensions of service quality. The first new factor comprises of different items related three dimensions originated from SERVQUAL, and SERVPERF dimensions, which are responsiveness, assurance and empathy. The combination of the five items produced new factor defined as institution relationship orientation. The second and third factors correspond significantly to SERVQUAL and SERVPERF dimensions. The second factor comprises of four items related to reliability and task related nature of the service. Therefore they were identified as factors associated with task related dimension. The third factor comprises three items associated with tangibles of the service including the institutions facilities and equipment. The three items in the third factor correspond significantly to the original items in SERVQUAL and SERVPERF dimension related to tangibles. Table 2 illustrates exploratory factor analysis for three factors in the research study.

Table 2. Exploratory Factor Analysis ( $n=107)$

\begin{tabular}{|c|c|c|c|}
\hline & \multicolumn{3}{|c|}{ Exploratory Factor Analysis } \\
\hline Item Description & Eigen Value & $\%$ of Variance & Factor Loading \\
\hline Factor 1 : Institution Relationship Orientation & 4.371 & 36.424 & \\
\hline 1. Employees understand your needs & & & .859 \\
\hline 2. Employees of the institute are polite & & & .850 \\
\hline 3. Employees of the institute deal with you in a caring fashion & & & .834 \\
\hline 4. Employees have the knowledge to answer your questions & & & .810 \\
\hline 5. Institute employees always willing to help you & & & .808 \\
\hline
\end{tabular}




\begin{tabular}{|c|c|c|c|}
\hline & & & \\
\hline Factor 2: Institution Task Orientation & 1.858 & 15.481 & \\
\hline 1. This institute perform services right the first time & & & .804 \\
\hline 2. This institute maintain error-free records & & & .734 \\
\hline 3. This institute is dependability in handling your problems & & & .713 \\
\hline 4. This institute provides services as promised you & & & .658 \\
\hline Factor 3: Institution Tangible facilities Orientation & 1.511 & 12.590 & \\
\hline 1. The institute s' facilities are visually appealing & & & .823 \\
\hline 2. The institute have modern equipment & & & .716 \\
\hline $\begin{array}{l}\text { 3. The appearance of the physical facilities of this institute is in } \\
\text { keeping with the type of services provided }\end{array}$ & & & .709 \\
\hline $\begin{array}{l}\text { Notes: Extraction Method: Principal Component Analysis. Rotatio } \\
4 \text { iterations. }\end{array}$ & & & \\
\hline
\end{tabular}

Source: author

\section{Reliability Analysis}

Cronbach Alpha analysis is conducted to measure the internal consistency of the three subscales. Reliability is a measurement that is established in testing the both consistency and stability. Cronbach's Alpha is "a reliability coefficient that indicates how well the items in a set are positively correlated to one another." In general, if the value of Cronbach's Alpha is at 0.60 it is considered as questionable. In behavioural and social sciences alpha of 0.60 would be an acceptable indication of reliability. If Cronbach's Alpha value is at 0.70 reliability is considered acceptable. If Cronbach's Alpha value is greater than 0.8 , it is considered as good. The closer to the value of one is Cronbach's Alpha, it results in higher internal consistency (Hair et al., 2010).

Table 3. Cronbach alpha reliability test $(n=107)$

\begin{tabular}{|l|l|l|}
\hline Variable Components & Number of Items & Alpha ( $\boldsymbol{\alpha})$ without deleting any item \\
\hline Institution Relationship Orientation & 5 & 0.90 \\
\hline Institution Task Orientation & 4 & 0.72 \\
\hline Institution Tangible facilities Orientation & 3 & 0.63 \\
\hline
\end{tabular}

Source: author

Reliability analysis shows various levels of internal consistency ranging from 0.63 to 0.90 indicating questionable to optimal reliability levels. Table 3 indicates reliability analysis for the research.

\section{Research Conceptual Framework}

This research paper examines the adaptation and employment of service quality scale instrument based mainly on SERVQUAL Parasuraman et al $(1988,1991)$ and SEVPERF (Cronin Jr. \& Taylor, 1994). This research paper examines service quality dimension where the emphasis is on perceived quality service only and not the comparison between expected service quality and perceived service quality adapting the approach employed by SERVPERF which maintains the perception of service quality without examining the expected service quality. The research study examines three dimensions of perceived service quality which are newly defined. The first dimension is identified as institution relationship orientation. The second dimensions is identified as institution task orientation. The third dimension is identified as institution 
tangible facilities orientation. The fourth dimension of the model identifies perceived price fairness and its relationship to the service; finally the fifth dimension of the model identifies student satisfaction with decision to use the service. The model examines a set of positive relationships between service quality dimensions, students' satisfaction with the service and price fairness. Figure 2 illustrates conceptual framework of service quality, price fairness and student satisfaction in Higher education.

\subsection{Research Variables}

\subsubsection{Institution relationship orientation}

Institution relationship orientation is newly defined approach of perceived service quality which reflects academic and administrative staff ability to demonstrate good levels of relationship and service providing support, assistance and knowledge in answering students' questions and requests. The new defined construct is a combination of dimensions based originally on SERVQUAL (Parasuraman, Berry, \& Zeithaml, 1991) and SEVPERF Cronin and Taylor (1992). Institution relationship orientation comprises subscales including (a) helpful, (b) polite, (c) knowledge to answer questions, (d) caring and (e) understanding of students' needs.

\subsubsection{Institution Task Orientation}

Institution Task Orientation is a dimension of service quality which reflects higher education institution ability to establish good standard levels of performance to students which has flawless records, right from the first time, demonstrating dependable and reliable service and providing service as promised to students. Institution Task Orientation dimension corresponds directly to reliability dimension which is based originally on SERVQUAL Parasuraman et al (1988, 1991) and SEVPERF Cronin and Taylor (1992). Institution Task Orientation comprises of subscales including (a) dependable service, (b) error - free records, (c) right the first time, and (d) service provided as promised.

\subsubsection{Institution Tangible Orientation}

Institution Tangible Orientation is a dimension of service quality which reflects higher education institutions' ability to demonstrate and provide standard levels of tangible aspects including facilities and availability of equipment's in the institution. Tangible dimension is based originally on SERVQUAL Parasuraman et al (1988, 1991) and SEVPERF Cronin and Taylor (1992). Institution Tangible Orientation compromise of subscales including (a) modern equipment, (b) facilities visually appealing and (c) physical facility keeping up with type of service.

\subsubsection{Price Fairness}

Price is the amount of money or goods used to attain some combination of other goods and its associated services (Tuan, 2012). Perceived price fairness in this study refers to one item adopted by Tuan (2012) applying a five-point Likert scale.

8.1.5 Student Satisfaction with Decision to use the Service Student Satisfaction with Decision to use the Service reflects student state of satisfaction with the service provided by the higher education institution. Student satisfaction is developed as a single item scale based originally by Oliver (1980). 


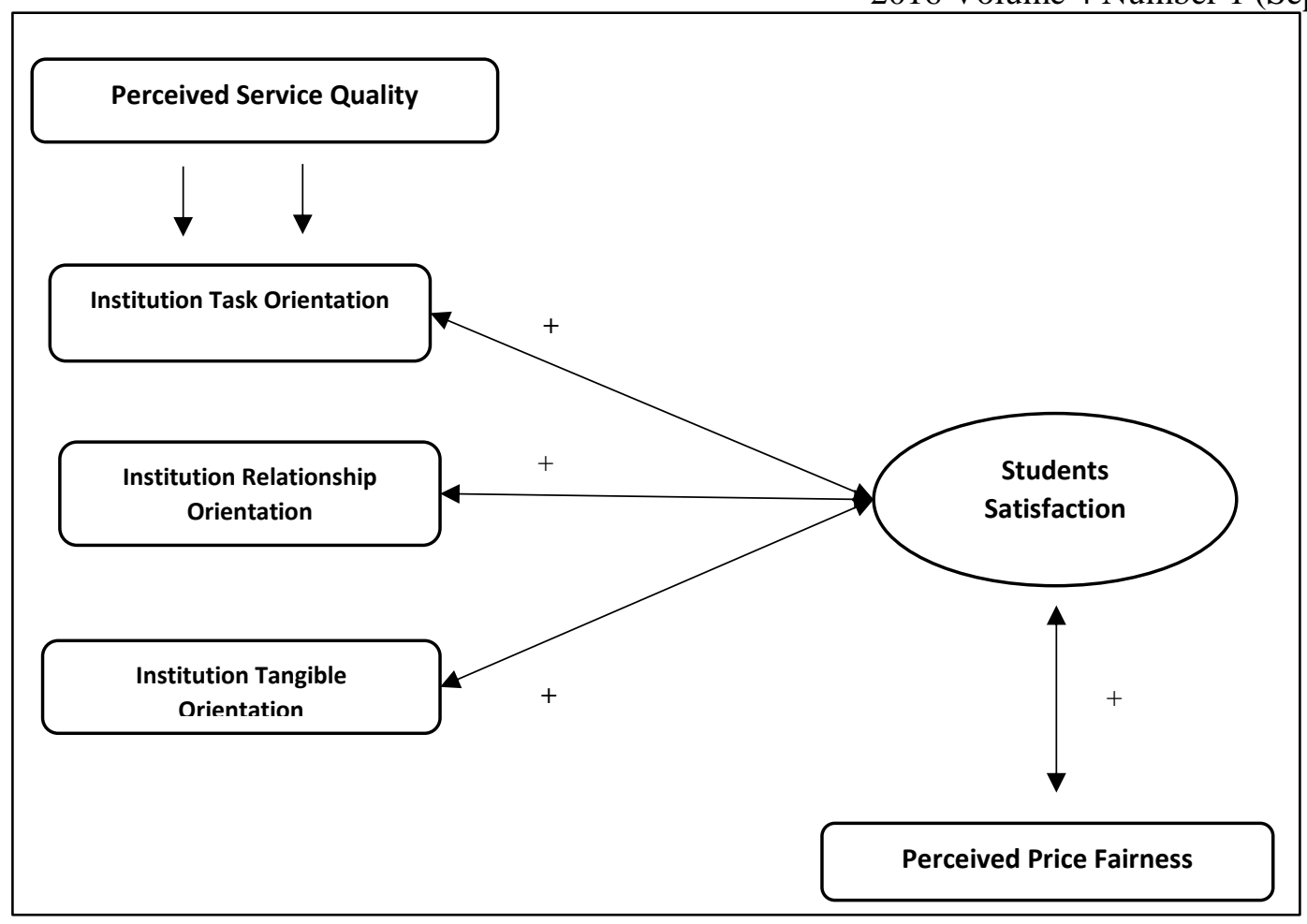

Figure 2. A Framework of Service Quality, Students Satisfaction and Price Fairness at Private Higher Education institution in Damascus Syria Source: author

\subsection{Research Hypotheses}

This research examines the application of perceived service quality in private Higher education institutions in Syria with a focus private universities operating in Damascus the capital of Syria. Against the background of a crisis in Syria which goes back to 2011, and the fact that private universities operating outside the capital of Damascus were requested by law to relocate their institutions and establishments to safer zones particularly within the capital of Damascus and relocate their faculties to temporary sites, the assumption for this research study is that quality of the services within private higher education institutions has deteriorated significantly. The fact that many Syrian academics who left Syria seeking better and safer life standards, leads to the assumption the quality of services provided by private higher education institutions has declined significantly. A prior study on SERVPERF instrument based on a sample of students from Syrian universities confirms that perceived service quality dimensions is an area of concern and development which requires further investigation and improvement (Mahmoud \& Khalifa, 2015). Against this background a set of research hypotheses are developed to examine perceived service quality dimensions:

H1. Perceived institution relationship orientation has an average rating among undergraduate students in the target higher education institutions.

H2. Perceived institution task orientation has below average rating among undergraduate students in the target higher education institutions.

H3. Perceived institution tangible orientation has below average rating among undergraduate students in the target higher education institutions. 
H4. Perceived institution relationship orientation is positively associated with students' satisfaction with decision to use the service

H5. Perceived institution task orientation is positively associated with students' satisfaction with decision to use the service.

H6. Perceived institution tangible orientation is positively associated with students' satisfaction with decision to use the service.

H7 Perceived price fairness is positively associated with students' satisfaction with decision to use the service.

\section{Descriptive Analysis}

Before testing the first set of three research hypotheses, normality tests must be performed to determine the selection of the statistical tests performed in this research study. Normality test was performed examining research variables. Shapiro Wilk test of indicates that data is normally distributed where percentage for institution relationship orientation $\mathrm{D}(107)=0.978, \mathrm{P}<0.05$; institution task orientation $\mathrm{D}(107)=0.983$, $\mathrm{P}<0.05$; and institution tangible orientation $\mathrm{D}(107)=0.977, \mathrm{P}<0.05$.

Descriptive analysis illustrates descriptive analysis of scale items comprising of 12 items measuring three dimensions of service quality. The individual item scores are illustrated in table 4 indicating the mean scores and standard deviation. Figure 3 illustrates three service quality grand means scores.

Table 4. Descriptive data analysis of Service quality $(n=107)$

\begin{tabular}{|l|c|c|}
\hline Institution Relationship Orientation & M & SD \\
\hline 1. $\quad$ Employees understand your needs & 2.78 & 1.02 \\
\hline 2. Employees of the institute are polite & 3.35 & 1.15 \\
\hline 3. Employees of the institute deal with you in a caring fashion & 2.86 & 1.16 \\
\hline 4. Employees have the knowledge to answer your questions & 3.09 & 1.07 \\
\hline 5. Institute employees always willing to help you & 3.17 & 1.30 \\
\hline
\end{tabular}

\begin{tabular}{|l|l|c|}
\hline Institution Task Orientation & M & SD \\
\hline 1. $\quad$ This institute provides services as promised you & 3.05 & .855 \\
\hline 2. $\quad$ This institute is dependable in handling your problems & 2.57 & 1.11 \\
\hline 3. $\quad$ This institute perform services right the first time & 2.60 & .929 \\
\hline 4. $\quad$ This institute maintain error-free records & 2.87 & 1.09 \\
\hline
\end{tabular}

\begin{tabular}{|l|c|c|}
\hline Institution Tangible Orientation & M & SD \\
\hline 1. The institute s' facilities are visually appealing & 2.25 & 1.11 \\
\hline 2. $\quad$ The institute have modern equipment & 2.88 & 1.16 \\
\hline 3. $\quad \begin{array}{l}\text { The appearance of the physical facilities of this institute is in keeping with the type of } \\
\text { services provided }\end{array}$ & 2.59 & .930 \\
\hline
\end{tabular}

Source: author 


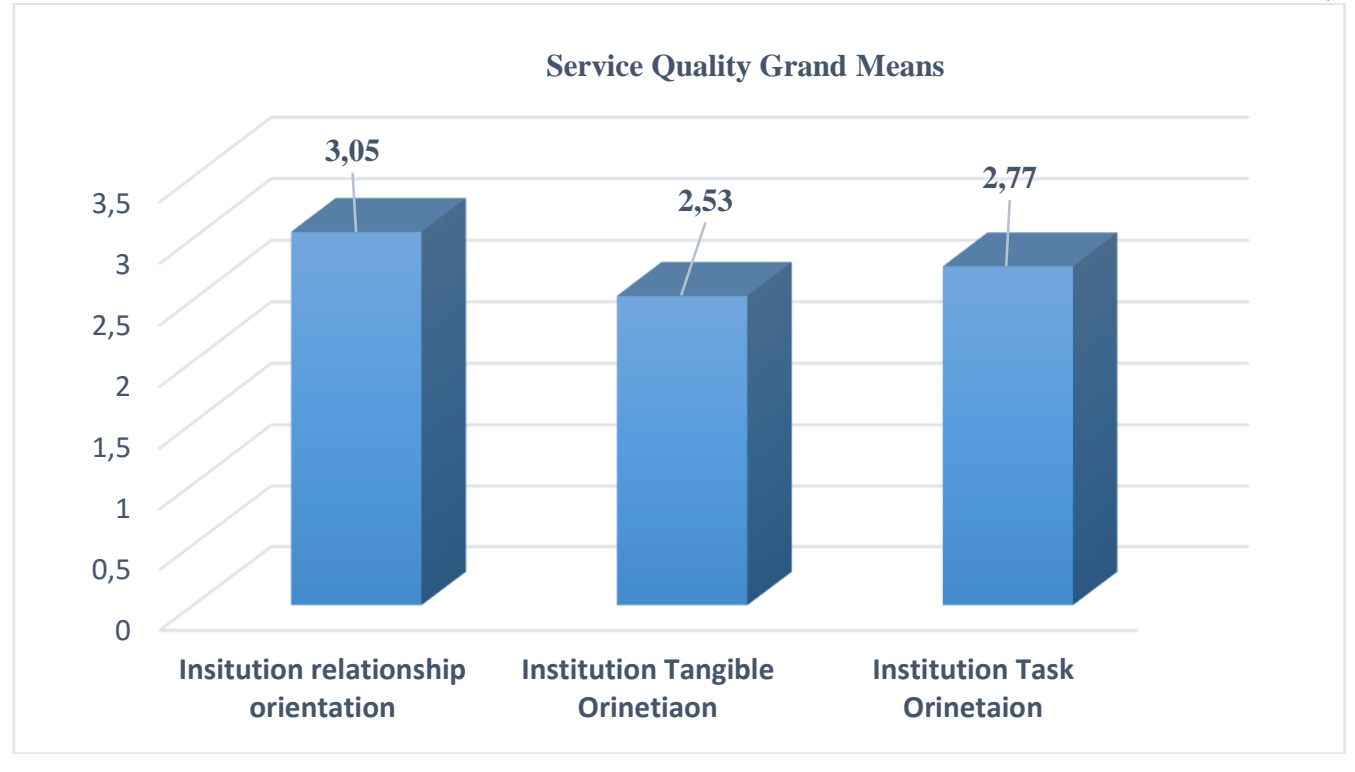

Figure 3 Service Quality Grand Means Source: author

To test the first set of hypotheses, one sample t test is conducted to examine the difference between the sample mean and population mean for research variables. The results of one sample t test for institution relationship orientation confirms that staff relationship orientation sample mean is not significantly different from population mean, where $\mathrm{t}(106)=0.595, \mathrm{p}=0.553$. The sample mean for perceived staff relationship orientation is not significantly different from population mean. This confirms that perceived institution relationship orientation is moderately perceived by undergraduate students of the sample study. The results of the $t$ test support the first hypothesis. The results of one sample $t$ test for perceived institution task orientation confirms that the sample mean is significantly different from the population mean, where $t$ $(106)=-3.083, p=0.003$. This confirms that perceived institution task orientation is negatively perceived by undergraduate students as they provide below average rating for this dimension. The results of $t$ test support the second hypothesis. The results of one sample $t$ test for perceived institution tangible orientation confirms that the sample mean is significantly different from population mean, where $t(106)=-6.346, \mathrm{p}=$ 0.000. This confirms that perceived institution tangible orientation is negatively or poorly perceived by undergraduate students of the research study as they provide below average score of this dimension. The results of $t$ test support the third hypothesis.

\section{Correlation Analysis}

As normality test indicated that the data for price fairness and students satisfaction with decision to use the service that the data was not normally distributed, attempts to deal with outliers and perform data transformation techniques were performed. Data transformation techniques including square root and LG10 were performed to improve the skewness of the data. These techniques were not successful. Therefore a non-parametric correlation analysis was performed to examine the association between the variables of the study. A Spearmen correlation analysis is conducted to measure the association between variables. Table 5 reports correlation analysis between variables. Correlation analysis conforms a significant and positive association between perceived institution relationship orientation and students' satisfaction with decision to use the service where $r_{s}=.34 * *, \mathrm{p}=.000$. The correlation analysis supports the fourth hypothesis. Correlation analysis conforms a significant and positive association between perceived institution task orientation and students' satisfaction with decision to use the service, where $r_{s}=.28 * *, p=.003$. The 
correlation analysis supports the fifth hypothesis. Correlation analysis does not indicate a significant relationship between perceived institution tangible orientation and students' satisfaction with decision to use the service, where $r_{s}=.11, \mathrm{p}=.232$. The correlation analysis fails to support the sixth hypothesis.

The correlation analysis confirms a positive and significant association between perceived price fairness and students satisfaction with decision to use the service at target universities of study, where $r_{s}=.41$, $\mathrm{p}=.000$. The correlation analysis support the seventh hypothesis. Figure 4 illustrates the correlational model examining the positive association between variables of the study. The results indicates that as service quality dimensions namely task and relationship oriented dimensions increase, students' satisfaction with decision about the service also increases. The result show that as students' satisfaction with the decision about the service increase their perception on price fairness also increase. The results do not indicate a strong association where all correlation coefficients are below 0.50 .

Table 5 Non-parametric Correlation Analysis

\begin{tabular}{|c|c|c|c|c|c|}
\hline Variables & 1 & 2 & 3 & 4 & 5 \\
\hline 1. Perceived Institution Task Orientation & 1 & & & & \\
\hline 2. Perceived Institution Relationship orientation & $\begin{array}{l}.33 * * \\
.000\end{array}$ & 1 & & & \\
\hline 3. Perceived Institution Tangible Orientation & $\begin{array}{l}.22 * \\
.018\end{array}$ & $\begin{array}{l}.22 * \\
.022\end{array}$ & 1 & & \\
\hline 4. Perceived Price Fairness & $\begin{array}{l}.33 * * \\
.000\end{array}$ & $\begin{array}{l}.18 \\
.056\end{array}$ & $\begin{array}{l}.34 * * \\
.000\end{array}$ & 1 & \\
\hline 5. Student satisfaction with decision to use service & $\begin{array}{l}.28 * * \\
.003\end{array}$ & $\begin{array}{l}.34 * * \\
.000\end{array}$ & $\begin{array}{l}.11 \\
.232\end{array}$ & $\begin{array}{l}.41 * * \\
.000\end{array}$ & 1 \\
\hline
\end{tabular}

Source: author

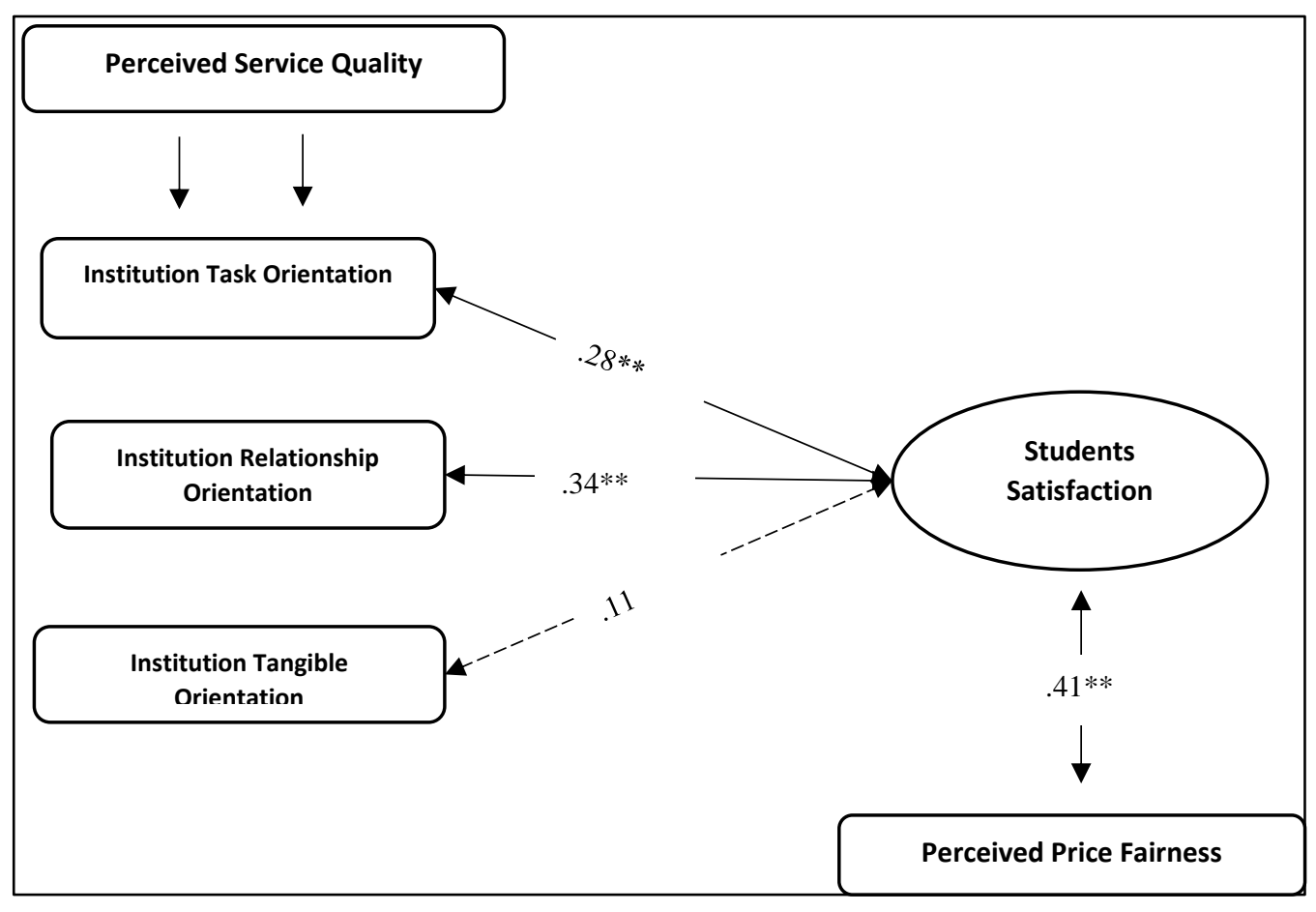

Figure 4. Correlation between Service Quality, Students' Satisfaction and Price Fairness Source: author 


\section{Discussion}

This research investigates the examination and application of newly defined service quality dimensions originated from Parasuraman et al $(1988,1991)$ and (Cronin Jr. \& Taylor, 1994). The assumption is that the application of this three dimensions model of service quality will assist higher education institutions detect areas of potential strength and weakness or development in private higher education institutions operating in Damascus, Syria. The crisis which has torn Syria over the past 6 years has left many sectors and institutions in a case of chaos and vulnerable. Higher Education institutions are no exception and they require careful examination of how their units and associations are performing. The research provides a significant contribution to the prior research on service quality in higher education in Syria. The research variables grand means illustrates below average to average levels of rating of service quality dimensions in higher education institutions of the research study. The research suggests that further examination and attention needs to be exercised to the above mentioned service quality levels. Descriptive data analysis confirms that service quality in higher education industry is an area of development that rrequires further examination and improvement. The research confirms that perceived service quality scores are below average to average rating, indicating that students of the target institution of the study perceive the service provided at the target private higher education institutions as below average to average. A previous study on SERVPERF dimensions applied in universities in Syria confirms similar findings (Mahmoud \& Khalifa, 2015). This research examines the relationship between service qualities, price fairness and students satisfaction in private higher education institutions in Syria. The results of the study confirm partially research hypotheses. The results of the research study indicate a positive but not strong relationship between perceived service quality, student satisfaction with the service and price fairness. There are limitations to be addressed in the following section.

\section{Limitations and Future Research}

The most evident limitation is related to sample size. Larger sample size is requested so that the research could perform both exploratory and confirmatory factor analyses. The measurement of adapted SERVQUAL scale and examination of validity and reliability of the scale requires a larger sample size, where validity analysis could be examined by conducting confirmatory factor analysis. The scale for students' satisfaction and price fairness is considered as a serious major limitation. With both students satisfaction with the service and perceived price fairness developed single item scales, the research study faced a limitation related to the normality of data and therefore the strength of the statistical tests applied. Single item scales also have issues related to reliability and validity. Future research on service quality scales in Higher Education in Syria could take into consideration the examination of larger research samples including private and public Higher Education institutions as the research topic is significant to this industry. Future research could examine further levels of measurement scales analysis taking into consideration the validity, reliability and practicality of the scale, as it is adapted from 7 points to 5 points Likert Scale and is translated to Arabic.

\section{Managerial Implication}

This research paper examined the application of SERVPERF dimensions and their effect on student satisfaction in higher education private institutions. The research study strongly recommends that further development and organizational focus is required to be exerted in this field related to service quality and its improvement. Training in the fields of customer service, customer relationships, and students' services is required and highly recommended. Students' satisfaction is a significant indicator of a higher education institution performance and effectiveness. The research study highly recommends application of service quality dimension in the higher education institutions. 


\section{Conclusion}

This research examined the relationship between service quality and customer satisfaction in private higher education institutions in Syria. The results confirms positive effect of service quality dimensions on students' satisfaction. The research provides support to prior research in the field of service quality in higher education.

\section{References}

Abdullah, F., Ahmad, N., Warraich, U. A., Qureshi, F. K., Nawaz, A., Qureshi, F. K., ... Sureshchandar, G. S. (2012). A conceptual study on the relationship between service quality towards customer satisfaction: Servqual and gronroos's service quality model perspective. Journal of Marketing, 3(1), 193-209. http://doi.org/10.5539/ass.v8n13p201

Aleksejeva, L. (2016). Country's competitiveness and sustainability: higher education impact, Journal of Security and Sustainability Issues 5(3): 355-363. http://dx.doi.org/10.9770/jssi.2015.5.3(4)

Bitner, M. J. (1990). Evaluating Service Encounters: The Effect of Physical Surrounding and Employee Responses. Journal of Marketing, 54(2), 69-82. Retrieved from http://www.jstor.org/stable/1251871 \nhttp://www.jstor.org/page/info/about/policies/terms.jsp

Ciemleja, G.; Lace, N. (2016). Opportunities for sustainable development and challenges in nanotech industry in Latvia, Journal of Security and Sustainability Issues 5(3): 423-436. http://dx.doi.org/10.9770/jssi.2016.5.3(10)

Čirjevskis, A. (2015). Sustainability in higher education: discourse on dynamic capabilities of privately run higher educational institutions (HEI) in Latvia, Journal of Security and Sustainability Issues 5(1): 111-122.http://dx.doi.org/10.9770/jssi.2014.5.1(9)

Cronin Jr., J. J., \& Taylor, S. A. (1994). SERVPERF Versus SERVQUAL: Reconciling Performance-Based and PerceptionsMinus-Expectations Measurement of Service Quality. Journal of Marketing, 58(1), 125-131. http://doi.org/10.2307/1252256

Djordjevic, a., \& Cotton, D. R. E. (2011). Communicating the sustainability message in higher education institutions. International Journal of Sustainability in Higher Education, 12(4), 381-394. http://doi.org/10.1108/14676371111168296

Dubauskas, G.; Balius, R. (2015). Management of public private partnership in education: aspects of public sector training sustainability issues, Journal of Security and Sustainability Issues 4(4): 345-352.http://dx.doi.org/10.9770/jssi.2015.4.4(3)

Douglas, J., Douglas, A., \& Barnes, B. (2006). Measuring Student Satisfaction at a UK University. Quality Assurance in Education: An International Perspective, 14(3), 251-267. Retrieved from http://dx.doi.org/10.1108/09684880610678568

Goyal, S. and Sergi, B. (2015). Social Entrepreneurship and Sustainability - Understanding the Context and Key Characteristics. Journal of Security and Sustainability Issues, 4(3), 269-278. http://doi.org/10.9770/jssi.2015.4.3(7)

Hair, J. F., Black, W. C., Babin, B. J., \& Anderson, R. E. (2010). Multivariate Data Analysis. Vectors. http://doi.org/10.1016/j.ijpharm.2011.02.019

Hidalgo, L. A., \& Fuentes, M. A. (2013). The Development of Basic Competencies for Sustainability in Higher Education: An Educational Model. US-China Education Review, Volume 3(Number 6), 498.

Kotler, P., \& Armstrong, G. (2013). Principles of Marketing. World Wide Web Internet And Web Information Systems, $42,785$. http://doi.org/10.2307/1250103

Mahmoud, A. B., \& Khalifa, B. (2015). A confirmatory factor analysis for SERVPERF instrument based on a sample of students from Syrian universities. Education + Training, 57(3), 1-19. http://doi.org/10.1108/ET-04-2014-0038

Merrill, N. (2011). Social media for social research: Applications for higher education communications. Cutting-Edge Technologies in Higher Education (Vol. 2). Emerald. http://doi.org/10.1108/S2044-9968(2011)0000002005

Nicholls, J., Harris, J., Morgan, E., Clarke, K., \& Sims, D. (1995). Marketing higher education: the MBA experience. International Journal of Educational Management, 9(2), 31-38. http://doi.org/10.1108/09513549510082369 
Oliver, R. L. (1980). A cognitive model of the antecedents and consequences of satisfaction decisions. Journal of Marketing Research, 17(November), 460-470. http://doi.org/10.2307/3150499

Parasuraman, A., Zeithaml, V. A., \& Berry, L. L. (1988a). Servqual - a Multiple-Item Scale for Measuring Consumer Perceptions of Service Quality. Journal of Retailing, 64(1), 12-40.

Parasuraman, A., Zeithaml, V., \& Berry, L. (1985). A Conceptual Model of Service Quality and its Implications for Future. Journal of Marketing, 49(4), 41-50. http://doi.org/10.2307/1251430

Parasuraman, A., Zeithaml, A. V., \& Berry, L. L. (1988b). SERVQUAL: A multiple-item scale for measuring consumer perceptions of service quality. Journal of Retailing, Volume 64(1), 12-40.

Parasuraman, a., Berry, L. L., \& Zeithaml, V. a. (1991). Refinement and Reassessment of the SERQUAL Scale. Journal of Retailing. http://doi.org/10.1111/j.1438-8677.2010.00335.x

Prause, G. (2015). Sustainable business models and structures for industry 4.0. Journal of Security and Sustainability Issues, 5(2), 159-169. http://doi.org/10.9770/jssi.2015.5.2(3)

Rosha, A.; Lace, N. 2015. Sustainable development and behavioural patterns: to innovations through coaching, Journal of Security and Sustainability Issues 5(2): 171-180. http://dx.doi.org/10.9770/jssi.2015.5.2(4)

Tuan, N. M. (2012). Effects of service quality and price fairness on student satisfaction. International Journal of Business and Social Science, 3(19 October), 132-151. Retrieved from https://www.academia.edu/9764615/Effects_of_Service_Quality_and_Price_Fairness_on_Student_Satisfaction

Tvaronavičienė, M.; Černevičiūtè, J. (2015). Technology transfer phenomenon and its impact on sustainable development, Journal of Security and Sustainability Issues 5(1): 87-97. DOI: http://dx.doi.org/10.9770/jssi.2015.5.1(7)

Valarie A. Zeithaml, M. J. B. and D. D. G. (2012). Services Marketing Integrating Customer Focus second European, 576.

Vojtovič, S.; Navickas, V.; Gruzauskas, V. (2016). Strategy of sustainable competitiveness: methodology of real-time customers' segmentation for retail shops, Journal of Security and Sustainability Issues 5(4): 489-

499.http://dx.doi.org/10.9770/jssi.2016.5.4(4)

Zeithaml, V., Berry, L. L., \& Parasuraman, A. (1996). The behavioral consequences of service quality. Journal of Marketing, 60(April), 31-46. http://doi.org/10.2307/1251929

Zikmund, W., Babin, B., Carr, J., \& Griffin, M. (2009). Business Research Methods

Dr. Serene DALATI is the Head of Management Department and a senior lecturer at the faculty of Business administration at the Arab International University, Syria. Dr. Dalati has obtained a PhD in Leadership, Organizational Culture and Job satisfaction in 2008 which was preceded by an MBA from Bangor University in 2002. Dr. Dalati teaches for areas in organizational Behaviour, Leadership, Culture and Job satisfaction. Fields of expertise of teaching also include Strategic Management, International Management, Marketing, and Entrepreneurial Small Business

Copyright (C) 2016 by author(s) and VsI Entrepreneurship and Sustainability Center This work is licensed under the Creative Commons Attribution International License (CC BY). http://creativecommons.org/licenses/by/4.0/

(c) (i) Open Access 